\title{
Pollution of Camel Milk by Heavy Metals in Kazakhstan
}

\author{
Gaukhar Konuspayeva $^{1}$, B. Faye*2 ${ }^{2}$ G. Loiseau ${ }^{3}$, E. Diacono ${ }^{2}$ and S. Akhmetsadykova ${ }^{1}$ \\ ${ }^{1}$ Al Farabi Kazakh National University, 71 av. Al Farabi, 050073 Almaty, Kazakhstan \\ ${ }^{2}$ CIRAD - Département Environnements et Sociétés, Campus International de Baillarguet, TA C-DIR / B 34398 Mont- \\ pellier Cedex 5, France \\ ${ }^{3}$ UMR Qualisud, CIRAD, TA B-95/16, 73, rue J.-F. Breton, 34398 Montpellier Cedex 5, France
}

\begin{abstract}
Environmental contamination by heavy metals is a common fact in Central Asia. In the present study two sampling procedures were achieved: (i) Sampling of fodder, camel raw milk and shubat (fermented camel milk) in 8 farms closed to pollution sources from the South of Kazakhstan for copper, iron, manganese, zinc, arsenic and lead analysis, (ii) sampling of camel milk in 4 regions of Kazakhstan (63 samples) analyzed for lead, chrome and zinc contamination. In first sampling, camel milk contained $0.07 \pm 0.04,1.48 \pm 0.53,0.08 \pm 0.03,5.16 \pm 2.17,<0.1$ and $0.025 \pm 0.02 \mathrm{ppm}$ respectively for $\mathrm{Cu}, \mathrm{Fe}, \mathrm{Mn}, \mathrm{Zn}, \mathrm{As}$ and $\mathrm{Pb}$. In shubat (fermented milk) the mean content was $0.163 \pm 0.164,1.57 \pm 0.46,0.088$ $\pm 0.02,7.217 \pm 2.55$ and $0.007 \mathrm{ppm}$ respectively. Arsenic was detected in some samples of milk and shubat only. The trace elements concentration increase in shubat compared to milk but lead concentration decreased. No clear correlation was observed with fodder composition. In second sampling, the lead content was on average $250 \pm 56$ ppb in the camel milk with no significant differences between regions. The maximum value was observed at Atyrau (532 ppb). Zinc content in milk $(5.42 \pm 0.2 \mathrm{ppm})$ did not change significantly between regions. In reverse, chrome $(59.5 \pm 45.4 \mathrm{ppb})$ was higher in Shymkent region compared to others.
\end{abstract}

These values were discussed according to the proximity of pollution sources. Specially, higher concentrations were experienced in fodder from pastures close to some industrial sites or high traffic road.

Keywords: Camel milk, lead/ heavy metals, trace element, Kazakhstan.

\section{INTRODUCTION}

The consumption of camel milk is very popular in Kazakhstan where it is known for its medicinal and dietary properties [1]. These properties are widely exploited for human health, as it is in several countries from the ex-Soviet Union [2] and developing countries [3]. The camel milk is considered to have anti-cancer [4], hypo-allergic [5] and anti-diabetic properties [6]. A high content in unsaturated fatty acids contributes to its overall dietary quality $[7,8]$. The low quantity of $\beta$-casein and the lack of $\beta$-lactoglobulin are linked to the hypo-allergic effect of camel milk. Other components such as the lactoferrin, immunoglobulins, lysozyme or vitamin $\mathrm{C}$ were reported to play a central part in the determinism of these properties $[9,10]$.

Kazakhstan is immersed in an "ecological crises", due to the specific place for nuclear test by Soviet government for long a time, and to the development of irrigation for cotton field linked with decreasing Aral Sea level. In addition, the manufacturing of metals and the minerals had high impact on environmental contamination, few control of rejecting contaminants being implemented. In that condition, camel milk could be contaminated and a source of intoxication for consumers. Some references on heavy metals content in cow

*Address correspondence to this author at the CIRAD - Département Environnements et Sociétés, Campus International de Baillarguet, TA C-DIR / B 34398 Montpellier Cedex 5, France; Tel: 33 (0)4 675937 03; Fax: 33 (0)4 675937 95; E-mail: faye@cirad.fr and breast milk are available. But concerning sheep and goat milk there are few references, and none on camel milk.

The heavy metals are responsible of many pernicious effect on human health as saturnisme (lead contamination), immunodepression and skin diseases (zinc and copper contamination), cancer (cadmium), hyperkeratosis of the members (arsenic), neurological disorders (manganese), or blood disorders (iron).

In the present study, it is established a first diagnosis of contamination status of camel in Kazakhstan by measuring some of the heavy metals in camel milk and in the feeding resources of the camel herds, especially in farms closed to potential sources of pollution.

\section{MATERIAL AND METHODS}

\section{Sampling Procedure}

Two sampling procedures were achieved:

(i) Eight farms were sampled for water, fodder and camel milk (herd mixed milk). The samples correspond to water and fodder consumed by camels. They belonged to 4 regions choosen for their potentially contaminated environment: Almaty, Aral, Atyrau, and Shymkent. Samples were taken from dromedary camels (one hump), Bactrian camels (two humps) and hybrids camels. The contaminating sources, as manufacturing, oil forages and spatial base were identified. 
Table 1. Mean Value and SD of the Trace Element and Heavy Metal Content in Fodder, Camel Milk and Shubat (in ppm) from Sample (i)

\begin{tabular}{|c|c|c|c|c|c|c|}
\hline & Cu & Fe & Mn & Zn & As & Pb \\
\hline \hline Fodder & $10.40 \pm 2.93$ & $793.69 \pm 630.48$ & $62.38 \pm 20.67$ & $32.95 \pm 27.15$ & $1.03 \pm 0.49$ & $4.28 \pm 9.60$ \\
\hline Milk & $0.07 \pm 0.04$ & $1.48 \pm 0.53$ & $0.084 \pm 0.03$ & $5.16 \pm 2.17$ & $<0.1$ & $0.025 \pm 0.019$ \\
\hline Shubat & $0.16 \pm 0.16$ & $1.57 \pm 0.46$ & $0.088 \pm 0.02$ & $7.212 \pm 2.55$ & $<0.1$ & $0.007 \pm 0.005$ \\
\hline
\end{tabular}

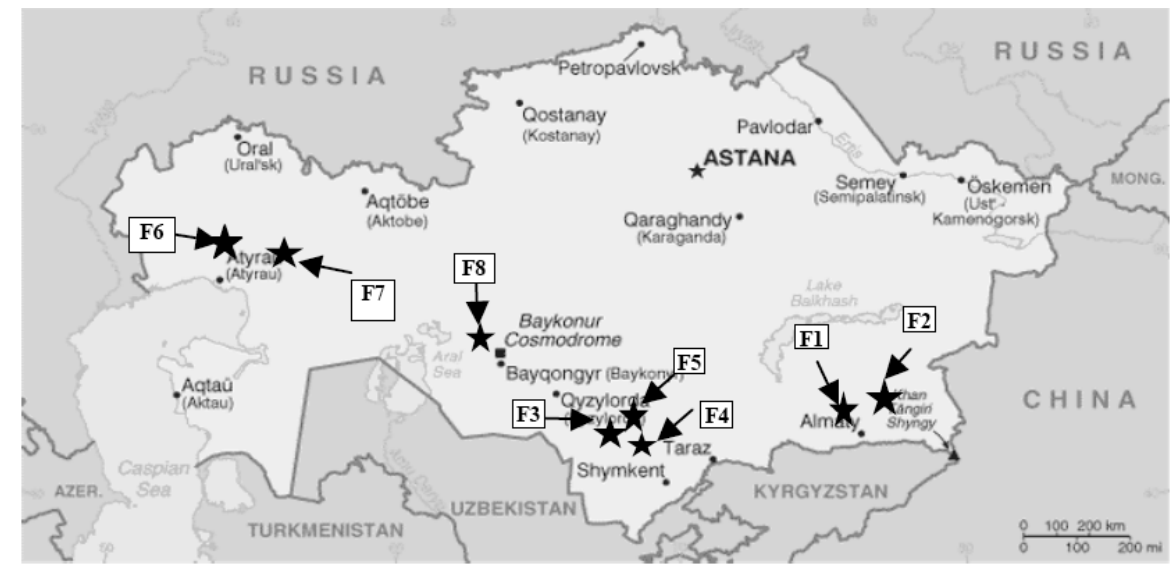

Map1. Sampling sites of camel milk and shubat in Kazakhstan, F1 to F8 - Farms.

When it was possible water and plants were sampled near these sources: in Almaty region, polymetal industries situated in Tekeli and Cary-Ozek were identified; in Atyrau region, oil forage, and in Aral Sea region the spatial base of Baikkanour were also identified. In Shymkent region, polymetal industries and phosphate manufacturing were recognized (Kengtaw, Aca) (Map 1).

(ii) In the same 4 regions of the country (Almaty, Aral, Atyrau, Shymkent), 63 milk samples of individual camel were collected in 12 farms (different than the first sampling) but still close to contaminating sources.

\section{Laboratory Analysis}

In the sample (i) copper, iron, manganese and zinc, arsenic and lead were analyzed. In the sample (ii) lead, chrome and zinc contamination were assessed.

In Kazakhstan, lead, copper, iron, zinc and chrome are currently used in industrial process and are discharged in the environment. Arsenic, manganese, copper and zinc are in non-negligible quantity in fertilizers widely used in degraded agriculture areas. However, our budget constraint has limited the number of analyzed parameters, notably in the sample (ii).

The analysis of heavy metals and trace elements in milk and shubat were achieved in two steps:

(1) Mineralisation by wet oxidation to destroy the organic matter in presence of nitric, sulphuric and perchloric acids. The advantage of this method, compared to the dry way method, is the lack of volatile elements loss. Ten $\mathrm{ml}$ of milk sample was added with nitric acid reagent $65 \%$ (Carlo Erba Reagents SA). Then the mixture was placed in a ceramic capsule on a heating plate up to $500^{\circ} \mathrm{C}$ for 4 hours. Nitric acid 65 $\%$ was added again on the ashes then evaporated on the heating plate up to the total destruction of the organic matter. When the solution was white, the solution was diluted up to $10 \mathrm{ml}$ with distilled water containing $1 \%$ nitric acid.

(2) Analysis of the solution by Atomic Absorption Spectrometry. This analysis was achieved by ICP methods (Inductively Coupled argon Plasma - Atomic Emission Spectrometer (ICP AES), Varian Vista MPX CCD), in laboratory of CIRAD- UR Qualisud (Montpellier-France). The quantification of the elements was performed by the standard addition method, using 11 point standard curve. AccuTraceTM Reference Standard solutions used were Quality Control Standard \#1Accu Standard ${ }^{\circledR}$ and Laboratory Performance Check Standard AccuStandard ${ }^{\circledR}$.

Similar analytical method was used for fodder (ICP analysis but after dry way mineralization and silica elimination by fluorhydric acid (HF). The detection limit for all the heavy metals was $0.01 \mathrm{ppm}$ except arsenic which was 0.1 ppm.

\section{Statistical Procedure}

Descriptive statistics were carried out (mean and standard deviation) for each heavy metal. Simple variance analysis was performed for assessing the region effect. The level of 


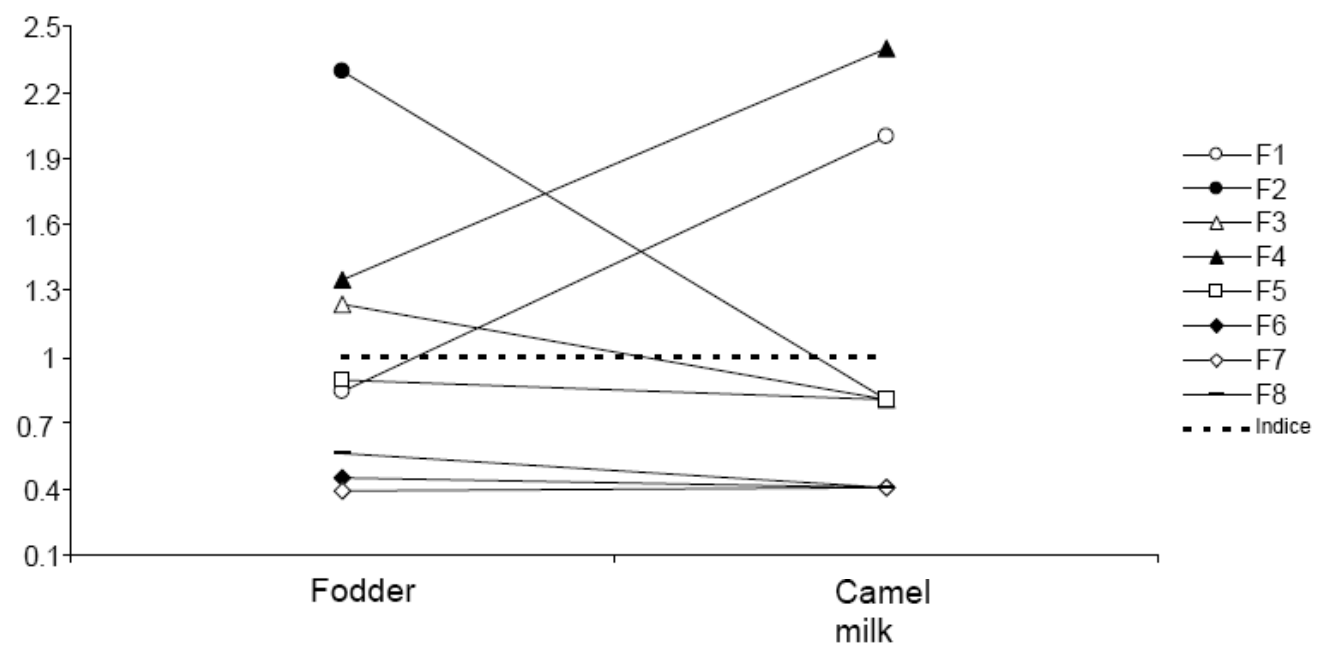

Fig. (1). Index of lead content in fodder and in camel milk in each sampled farm (sample i).

concentrations could vary considerably according to the matrix (milk or fodder) and according to the element. So, in order to compare these concentrations whatever the matrix or element, an index was used. This index was calculated for each type of sample (milk or fodder) as follow:

$$
\mathrm{I}=\mathrm{x}^{\mathrm{ij}} / \operatorname{mean}\left(\mathrm{x}^{\mathrm{i}}\right)
$$

Where $\mathrm{x}^{\mathrm{ij}}$ was the concentration $\mathrm{x}$ for the element $\mathrm{i}$ and the sample j.

$\operatorname{Mean}\left(\mathrm{x}^{\mathrm{i}}\right)$ was the mean of all concentrations for the element i.

If the concentration for a determined element was equal to the mean, the index will be 1 . So, the change in the concentration from one matrix to another will be assessed according to its difference to the mean, whatever the absolute value of the concentration.

Correlations between values in fodder and milk or between values in milk and shubat were assessed by the Pearson correlation test.

\section{RESULTS}

\section{Samples (i)}

\section{Trace Elements Contents in Water, Fodder and Camel Milk}

In water, no contaminants were detected. In fodder (Table 1), the trace-element concentrations were on average (in ppm) 10.4 (copper), 62.38 (manganese) and 32.95 (zinc). In comparison, the iron concentration appeared very high (793.69 ppm) with a maximum value of 2533 ppm (farm 4Shymkent region). On average, lead concentration was 4.28 $\pm 9.60 \mathrm{ppm}$ and arsenic, $1.03 \pm 0.49 \mathrm{ppm}$ (Table 1). The highest value of lead in fodder was $34.90 \mathrm{ppm}$ and was obtained in sample of Kengtaw near a polymetal industry in Shymkent region. On average, this fodder sample was also richer in manganese (82.1 ppm), zinc (94.3 ppm) and arsenic (1.6 ppm).

The mineral content in camel milk was between 0.07 ppm for copper and $5.16 \mathrm{ppm}$ for zinc (Table 1). The lead concentration was on average $0.025 \pm 0.02 \mathrm{ppm}$, with a maximum value of $0.06 \mathrm{ppm}$ reported in milk sample from the farm $n^{\circ} 4$ (Shymkent region). The arsenic concentration was under analytical limit (less than $0.1 \mathrm{ppm}$ ).

In shubat, the concentrations in trace elements were close to those of milk, but the lead content was lower (Table 1).

\section{Links Between Trace Element and Heavy Metals Content in Fodder and in Camel Milk}

The links between trace element concentration in fodder and milk or between heavy metals concentration in fodder and milk changed according to the involved element. For copper, manganese and zinc, two groups of farms were identified: one group with index in milk lower than index in fodder, and another group with increasing index from fodder to milk. For lead, non-natural element, similar trend was observed (Fig. 1).

However, there was no correlation on average between the content of one element (trace element and heavy metal) in fodder and the content of the same element in camel milk. Yet, the copper and manganese concentration in milk was significantly correlated with zinc content in fodder $(r=0.724$ and $r=-0.725)$, and lead concentration in milk was significantly correlated with iron and manganese content in fodder $(\mathrm{r}=0.897, \mathrm{r}=0.815)$.

\section{Relationships Between Raw Milk and Shubat Mineral Con- tents}

The relationship in mineral content of raw camel milk and shubat was observed on 6 farms only because shubat samples were lacking in the farms 1 and 6 . Concerning $\mathrm{Cu}$ content, generally, mean value of this mineral in shubat was higher than mean for raw milk (Fig. 2). Similar pattern was observed for iron (Fig. 3) and zinc (Fig. 4), but the relation was not so clear for manganese (Fig. 5). Conversely, lead content decreased in shubat and was not detectable in 2 samples from farms 4 and 5, although the maximal value was detected in milk of farm 4 (0.06 ppm) (Fig. 6). As the whole, the mineral composition of milk was correlated to mineral composition of shubat $(\mathrm{r}=0.692, P<0.0001)$. 


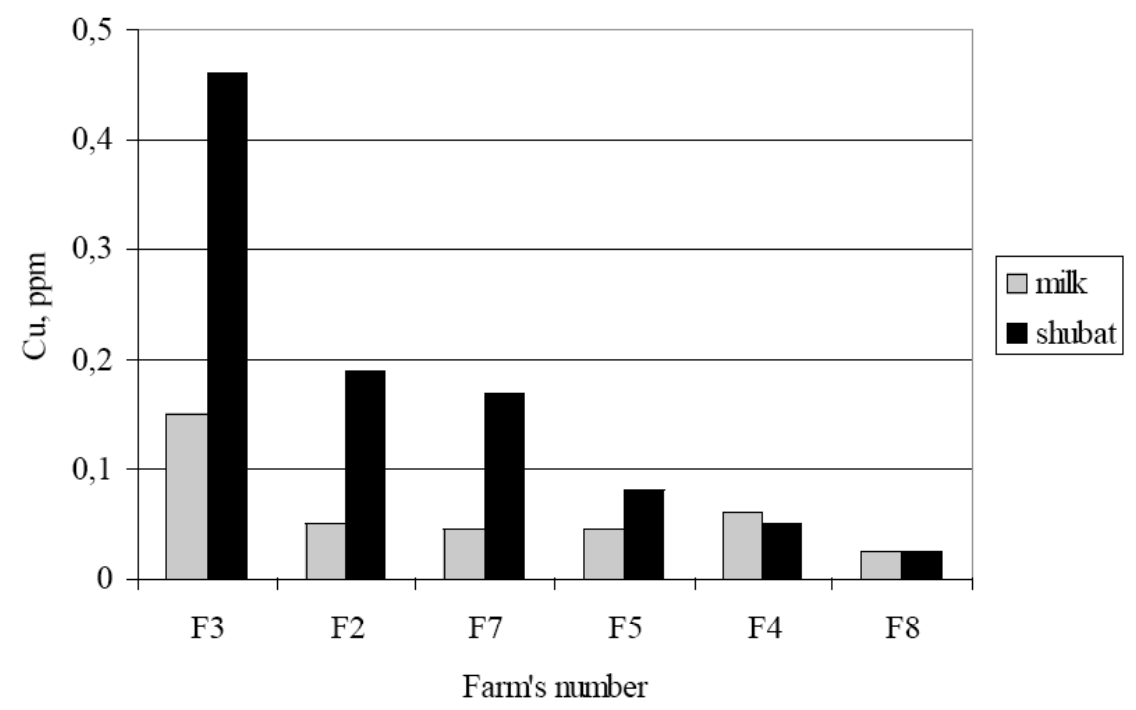

Fig. (2). Cu content in camel milk and shubat (in ppm). The farms are sorted according to the descending values in shubat (sample i).

Table 2. Lead, Zinc and Chrome Content in Raw Camel Milk ( $n=63)$ from 4 Regions in Kazakhstan

\begin{tabular}{|c|c|c|c|}
\hline & Pb, ppb & Zn, ppm & Cr, ppb \\
\hline \hline Almaty & $245.94 \pm 34.69^{\mathrm{a}}$ & $48.62 \pm 1.52^{\mathrm{a}}$ & $46.91 \pm 37.69^{\mathrm{a}}$ \\
\hline Atyrau & $244.18 \pm 83.66^{\mathrm{a}}$ & $59.90 \pm 1.69^{\mathrm{a}}$ & $43.12 \pm 21.03^{\mathrm{a}}$ \\
\hline Aralsk & $249.20 \pm 50.29^{\mathrm{a}}$ & $57.08 \pm 2.21^{\mathrm{a}}$ & $38.12 \pm 15.96^{\mathrm{a}}$ \\
\hline Shymkent & $260.50 \pm 35.00^{\mathrm{b}}$ & $52.13 \pm 2.49^{\mathrm{a}}$ & $96.19 \pm 56.68^{\mathrm{b}}$ \\
\hline
\end{tabular}

${ }^{\mathrm{a}, \mathrm{b}}$ Means in a column with common superscripts do not differ.

\section{Sample (ii)}

The lead content was on average $250 \pm 56 \mathrm{ppb}$ in the camel milk with no significant differences between regions (Table 2) except a slightly significant higher concentration in the samples from Shymkent $(P<0.05)$. The maximum individual value was observed anyway at Atyrau (532 ppb). Zinc content in milk $(5.42 \pm 0.2 \mathrm{ppm})$ did not change significantly between regions. Conversely, chrome (59.5 \pm 45.4 $\mathrm{ppb})$ was also significantly higher in Shymkent region compared to others $(P<0.01)$.

\section{DISCUSSION}

The comparison with the rare data in the literature could be uneasy as the analytical methods used varied considerably. Secondly, the measured quantities were generally very low, even in case of contamination, conducting to a high variability of the observed values in the space and in the time. However, general trends could be reported.

\section{Trace Elements and Heavy Metals in Fodder}

In this study, trace element concentrations in fodder samples were in the normal range of values. The sample from the farm 4 (Shymkent region) contained a quite higher iron quantity $(2533 \mathrm{ppm})$ compared to the other samples. Iron content in fodder and grass was generally highly variable because the contamination of samples could occur easily. But iron contamination (provoking siderosis in human) could be linked also to the source of polymetal factory.
The manganese content in fodder $(62.38 \mathrm{ppm})$ was in agreement with the results reported by Caggiano et al. [11] in Italia, in areas exposed to some industrial contamination $(101 \pm 85 \mathrm{ppm})$.

The lead contents in our fodder sample were on average, higher than Caggiano et al. [11] (1.2 $\pm 1.1 \mathrm{ppm})$. The sample from Kengtaw (farm 4) was particularly high (34.9 ppm) and could be directly attributed to the polymetal manufacturing close to the farm. Indeed, the factory enriched different ores, containing lead, for mineral extraction, and the unused lead rejection in the atmosphere was reported as an important risk of air pollution in the area [12].

\section{Trace Elements and Heavy Metals in Milk and Shubat}

According to the literature, human activities close to the sampling area influence the concentration of heavy metals in milk. Especially, traffic road intensity plays a role on lead content in cow milk [13]. In northern countries, the use of un-leaded gasoline has decreased strongly the role of traffic road in lead contamination. In Europe, the part of road traffic in total emission of lead decreased from $93 \%$ in 1990 to $4 \%$ in 2000 thanks to the use of un-leaded gasoline [14]. In Kazakhstan, the gasoline used in cars is still containing lead in high quantity. In similar situation, for example in India, the lead content in milk was positively correlated to the traffic density, (from $360 \mathrm{ppb}$ on average for a traffic density of 10 vehicles per day to $7200 \mathrm{ppb}$ on average for a traffic density of 15000 vehicles per day) [15]. Lead concentration in 


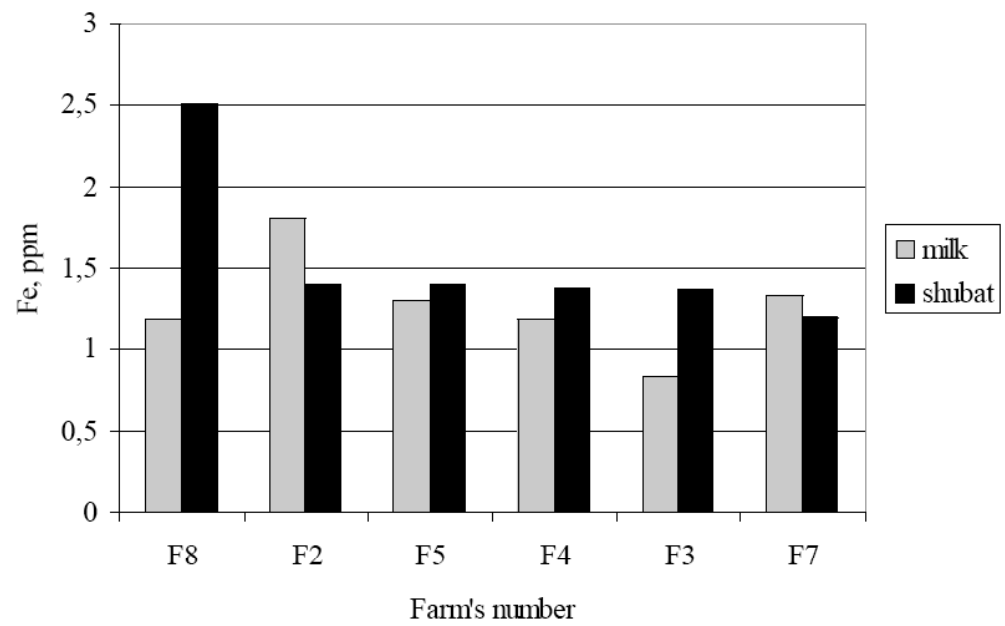

Fig. (3). Fe content in camel milk and shubat (in ppm). The farms are sorted according to the descending values in shubat (sample i).

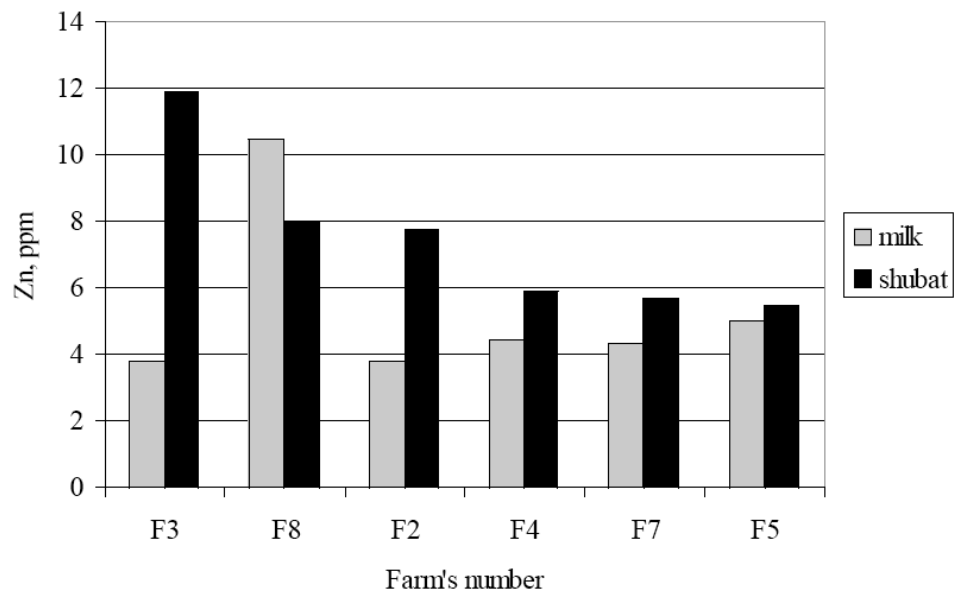

Fig. (4). Zn content in camel milk and shubat (in ppm). The farms are sorted according to the descending values in shubat (sample i).

cowmilk was on average of $1.32 \mathrm{ppb}$ in rural area [16], of $250 \mathrm{ppb}$ in industrial area [17], and of $320 \mathrm{ppb}$ close a road [18]. In our study, it was difficult to attest if lead contamination of camel milk was important or not, as no reference was available for this species. However, the presence of lead in fodder or milk is not normal, and consequently contamination could be strongly expected. Reported values in our first sample were on average higher than the tolerable value of 20 $\mathrm{ppb}$ proposed in Turkey, but under the normal value of 50 ppb considered in Germany and Holland and 100 ppb in Kazakhstan. In industrial area, lead concentration of cow milk varied from $49 \mathrm{ppb}$ [18] to $67 \mathrm{ppb}$ [19], with higher mean value of $844 \mathrm{ppb}$ near zinc and lead smelter [20]. Two of our monitored farms showed quite higher lead content in camel milk, the farm 1 (Almaty region) and the farm 4 (Shymkent region): respectively $50 \mathrm{ppb}$ and $60 \mathrm{ppb}$. Taking in consideration all these informations, it was possible that the highest lead concentration in milk in these farms could be due to the proximity of road with heavy traffic, leaded gasoline being still widely used in the country. Conversely, the lead concentration in the second sample was quite important and higher than the tolerable value.

Concerning other heavy metals, few references were available. Zinc content in milk seems to be in the normal range even in animals reared near industrial or traffic areas, although milk from industrial area contained significantly more zinc than in traffic or rural area, $5.01 \mathrm{ppm}, 4.49 \mathrm{ppm}$ and 3.77 ppm respectively [16].

For copper, observations were similar: the proximity of industrial area increased significantly the copper concentration in cow milk as well as traffic area, cow milk from rural area containing less copper $(0.96 \mathrm{ppm}, 0.58 \mathrm{ppm}$ et $0.39 \mathrm{ppm}$ respectively) [16].

For iron, human activities as industrial plants, traffic road, increased significantly the content in cow milk towards rural area (4.27ppm, $1.78 \mathrm{ppm}, 1.01 \mathrm{ppm}$ respectively) [16].

Arsenic content in camel milk in this study was not determinate precisely $(<100 \mathrm{ppb})$. Nevertheless, the observed value was in accordance with literature. Simsek et al., [18], Licata et al., [16] and Meldebekova et al., [17] using more sensitive colorimetric methods reported values of arsenic concentration in milk less than $100 \mathrm{ppb}$ : $50 \mathrm{ppb} ; 37.9 \mathrm{ppb}$ and $21.8 \pm 57 \mathrm{ppb}$ respectively. Arsenic concentration in milk varies according to sampling place. Thus, cows in rural areas produced milk containing $0.2 \mathrm{ppb}$ arsenic on average. In industrial area and traffic road area, those values were 40 


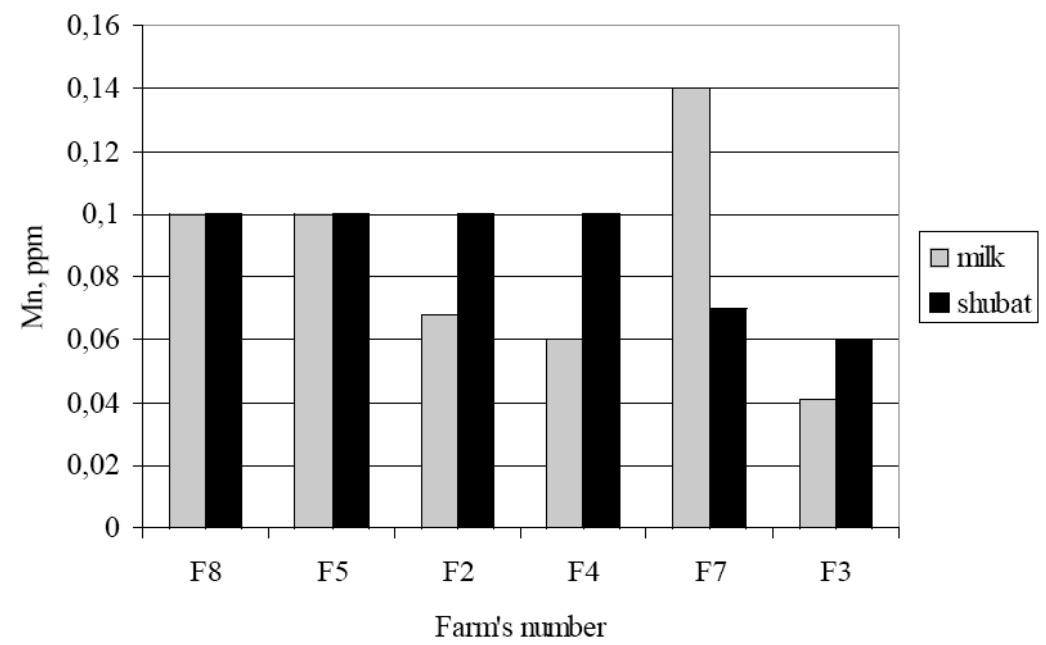

Fig. (5). Mn content in camel milk and shubat (in ppm). The farms are sorted according to the descending values in shubat (sample i).

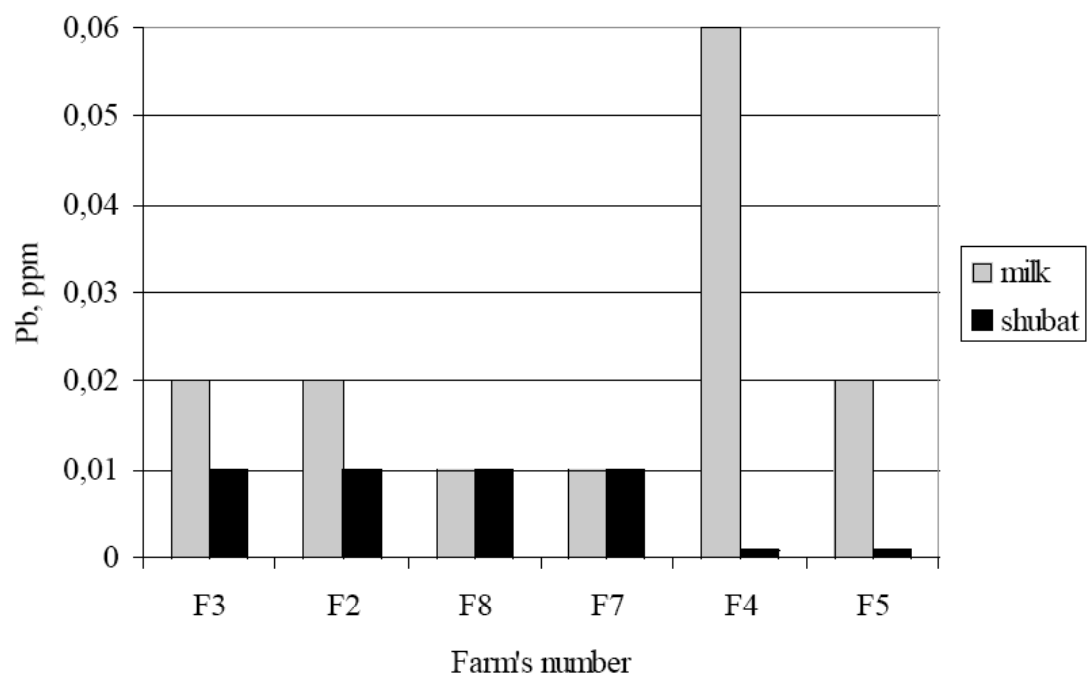

Fig. (6). $\mathrm{Pb}$ content in camel milk and shubat (in ppm). The farms are sorted according to the descending values in shubat (sample i).

and $50 \mathrm{ppb}$ respectively [18]. The higher reported values were from $120 \mathrm{ppb}$ [15] to $684 \mathrm{ppb}$ [16] in industrial area.

No reference concerning chrome was available on camel milk, but some samples appeared with widely higher concentration than the tolerable values in cow milk. So, contamination could be expected.

Very few references were available on shubat, but it is admitted that the normal values were similar to those for raw milk. The increase of trace-element content in shubat compared to milk was unclear, but was already reported. For example, Saitmuratova et al., [21] found 2 to 3 more iron in shubat than in raw milk (on average 77 and $32 \mathrm{mg} / \mathrm{L}$ ). These very high values could be debatable and could be attributed to the analytical methods: we used spectrometry ICP although, Saitmuratova et al., [21] used Neutron Activation Analysis.

The As concentration in shubat was less than $100 \mathrm{ppb}$. No data was available on the As concentration in fermented camel milk but according to the Kazakh standard camel shubat should not contain more than $55 \mathrm{ppb}$.
Contrary to trace-elements, the lead concentration decrease in all shubat samples compared to the raw milk even to likely contaminated milk. This is an interesting fact, because it is suspected a role of lactic bacteria in the detoxification of camel milk. This aspect has been under study [22].

\section{Links Between Mineral Content in Fodder and Milk}

No references were available on this aspect. All investigations on contamination of milk by heavy metals, didn't take into account the intake of contaminants by the feeding. No correlation between fodder and milk content of heavy metals and trace elements was observed in our study, but the number of samples was not sufficient for sound conclusion. However, according to recent observations using GIS and reported in the same farms [23], an effect of distance from the pollution source of contamination on lead concentration in milk (case of farms 1 and 4), and on fodder content of zinc, manganese, arsenic and lead seemed to be observed. Elsewhere, the soil contamination by pollutants appeared more important than fodder. Thus, soil could be intake by herbivorous feeding on natural pasture in high quantity (up to $10 \%$ ), then to play a more important role in the contami- 
nation of the animals. So, the correlation could be better between contaminant concentration in soils and contaminant concentration in animal product [24].

\section{CONCLUSION}

The present investigation on contamination status of fodder and camel milk by heavy metals in Kazakhstan was a preliminary work showing some trends in the effect of environmental pollution on heavy metal composition of milk, although the number of samples was limited. The relationships between heavy metals content in water, fodder and milk could be specified by including complementary data as soil contamination, and determination of zones at risk according to the proximity of pollution sources.

The collect of these data are on the way and will include more milk and fodder samples, and the assessment of risk pollution indicator based on the distance to the pollution source, the dominating wind and the topography of the farm area (watersheds, type of soils, type of vegetation).

\section{ACKNOWLEDGEMENT}

The present work was supported by the cooperation service of the French Embassy in Kazakhstan in the frame of a scientific cooperation between Al-Farabi University (Almaty- Kazakhstan) and the Centre of International cooperation for agronomic research on development -CIRAD, Montpellier -France).

\section{ABBREVIATIONS}

$\begin{array}{lll}\mathrm{As} & = & \text { Arsenic } \\ \mathrm{Cd} & = & \text { Cadmium } \\ \mathrm{Cu} & = & \text { Copper } \\ \mathrm{ICP} & = & \text { Induced Coupled Plasma } \\ \mathrm{Mn} & = & \text { Manganese } \\ \mathrm{Pb} & = & \text { Lead } \\ \mathrm{ppm} & = & \text { part per million } \\ \mathrm{ppb} & = & \text { part per billion } \\ \mathrm{Zn} & = & \text { Zinc }\end{array}$

\section{REFERENCES}

[1] Faye B, Konuspayeva G, Messad S, Loiseau G. Discriminant milk components of Bactrian camel (Camelus bactrianus), dromedary (Camelus dromedarius) and hybrids. Dairy Sci Technol 2008; 88: 607-17.

[2] Kenzhebulat S, Ermuhan B, Tleuov A. Composition of camel milk and it's use in the treatment of infectious diseases in human. Proceeding of $2^{\text {nd }}$ Camelid Conference, Agroeconomics of camelid farming. Almaty (Kazakhstan); AgroMerkur Publishers 8-12 $2^{\text {th }}$ September 2000; p. 101.

[3] Mal G, Sena DS, Jain VK, Sahani MS. Therapeutic value of camel milk as a nutritional supplement for multiple drug resistant (MDR) tuberculosis patients. Israel J Vet Med 2006; 61: 88-91.

[4] Magjeed NA. Corrective effect of milk camel on some cancer biomarkers in blood of rats intoxicated with aflatoxin B1. J Saudi Chem Soc 2005; 9: 253-630.
[5] Shabo Y, Barzel R, Margoulis M, Yagil R. Camel milk for food allergies in children. Immunol Allergy 2005; 7: 796-8.

[6] Agrawal RP, Swami SC, Beniwal R, et al. Effect of camel milk on glycemic control, risk factors and diabetes quality of life in type-1 diabetes: a randomised prospective controlled study. J Camel Pract Res 2003; 10: 45-50.

[7] Karray N, Lopez C, Ollivonn M, Attia H. La matière grasse du lait de dromadaire: composition, microstructure et polymorphisme, Une revue. Oleaginous Fat Matter Lipid 2005; 12: 439-46.

[8] Konuspayeva G, Lemarie E, Faye B, Loiseau G, Montet D. Fatty acid and cholesterol composition of camel's (Camelus bactrianus, Camelus dromedarius and hybrids) milk in Kazakhstan. Dairy Sci Technol 2008; 88: 327-40.

[9] El-Agamy EI, Ruppanner R, Ismail A, Champagne CP, Assaf R. Purification and characterization of lactoferrin, lactoperoxydase, lysozyme and immunoglobulins from camel's milk. Int Dairy J 1996; 6: 129-45

[10] Konuspayeva G, Faye B, Loiseau G, Levieux D. Lactoferrin and Immunoglobin content in camel milk from Kazakhstan. J Dairy Sci 2007; 90: 38-46.

[11] Caggiano R, Sabia S, D'Emilio M, et al. Metal levels in fodder, milk, dairy product, and tissues sampled in ovine farms of southern Italy. Environ Res 2005; 99: 48-57.

[12] Esekin BK, Bogachev VP, Duskaev KK, Rodionov AM, Medvedeva Y. National Environmental Center for Sustainable Development of the Republic of Kazakhstan. In: Daukeev S, Zh. Bekeev, A.T. Eds. Ministry of Natural Resources and Environmental Protection of the Republic of Kazakhstan, 2000, Available from: http://enrin.grida.no/htmls/kazahst/soe2/soee/index.htm

[13] Sleiman H. Atmospheric pollution: blood lead levels and car traffic pollution in Beirut. Pollut Atmos 2000; 42: 197-221.

[14] Snakin VV, Prisyazhnaya AA. Lead contamination of the environment in Russia. Sci Total Environ 2000; 256: 95-101.

[15] Bhati I, Choudhri GN. Lead poisoning of milk-The basic need for the foundation of human civilization. Indian J Public Health 1996; 40: 24-6.

[16] Licata P, Trombetta D, Cristani M, et al. Levels of "toxic" and "essentials" metals in samples of bovine milk from various dairy farms in Calabria, Italy. Environ Int 2003; 30: 1-6.

[17] Meldebekova A, Diacono E, Konuspayeva G, Faye B. Heavy Metals and trace elements content in camel milk and shubat from Kazakhstan. In: Faye B, Sinyavskiy Y, Eds. Proceeding of Intl Workshop, Impact of pollution on animal products 27-30 September 2007. Almaty (Kazakhstan). Merkilli Publications. 2008; pp. 11723.

[18] Simsek O, Gültekin R, Öksüz O, Kurultay S. The effect of environmental pollution on heavy metal content of raw milk. Nahrung 2000; 44: 360-3.

[19] Dey S, Swarup D. Lead concentration in bovine milk in India. Arch Environ Health 1996; 51: 478-9.

[20] Swarup D, Patra RC, Naresh R, Kumar P, Shekhar P. Blood lead levels in lactating cows reared around polluted localities; transfer of lead into milk. Sci Total Environ 2005; 349: 67-71.

[21] Saitmuratova OKH, Sulaimanova GI, Sadykov AA. Camel's milk and shubat from the aral region. Chem Nat Compd 2001; 37: 5668

[22] Akhmetsadykova S. Interactions entre les bactéries lactiques et les métaux lourds. Master report: Nutrition, Agrovalorisation en Santé Publique. France Montpellier University II, 2008; pp. 46.

[23] Le Guillou M. Diagnostic et cartographie des risques de pollution de l'environnement (eau, plantes, sols) par les métaux lours autour des fermes camélines au Kazakhstan. Mémoire de master, France Université de Montpellier II, 2009; p. 50.

[24] Jurjanz S, Rychen G, Feidt C. Dairy livestock exposure to persistent organic pollutants and their transfer to milk: a review. In: Faye B, Sinyavskiy Y, Eds. Proceeding of Intl Workshop, Impact of pollution on animal products. 27-30 September 2007, Almaty (Kazakhstan), 2008; pp. 63-84. 